to the British Association last month? The Government also has to decide how much it can afford to pay the victims of the latest floods-should the financial load fall on the general body of taxpayers or should individuals be more responsible for their own insurance ?

The Meteorological Office has come in for a share of the prevailing blame for failing utterly to predict even that there might be heavy rain. It has defended its recently acquired computer, with its ability to "forecast many features of the weather", by explaining that there is no computer anywhere sufficiently powerful to make accurate forecasts on a day to day basis.

The Natural Environment Research Council is supporting a research project to be undertaken at the Institute of Hydrology on the prevention and forecasting of floods in England. Large scale investigations of the entire tidal length of the Thames are also under way (Nature, 219, 1097) and everybody now hopes that a barrier will be built across the Thames to ensure that London is never flooded.

\section{WATER POLLUTION \\ Cleaning Up the Trent}

Conservationists and gourmets may jump with joy at the news given in the latest annual report of the Trent River Authority that two spent cock salmon have been caught in the river near Newark-the first salmon to be landed in the Trent since 1931. Celebration may, however, be premature, for the salmon in question were caught nearly two years ago, in January 1967 , and there have been no more since then. Indeed, when the salmon were caught the water conditions in the Trent were rather better than usual because of heavy falls of rain, and it was the end of the year when the fish had probably moved upstream. The fact that the fish had spawned was one good sign, but the reappearance of the salmon does not necessarily mean that the river is getting cleaner, although $\mathrm{Mr} \mathrm{C}$. A. Hobday, deputy pollution and fisheries officer, said this week that the river has improved slightly during the past five years-not before time. In the summer months, about a third (250 million gallons) of the 750 million gallons of water flowing past Nottingham is sewage effluent, and the proportion of sewage to natural water is likely to increase unless measures are taken to improve the network of sewage systems and the sewage treatment works. The Trent is not alone in Britain in being so polluted, of course, but it does have a serious problem peculiar to itself. About $\mathbf{5 \cdot 5}$ million people live within the Trent catchment area, nearly half of them around the head waters of the Trent and its tributary, the Tame. This means that there is very large pollution at the source of the system and not, as is more usual, at the mouth.

The problems of the Trent are therefore very large, and this is why a special committee, the Trent Steering Committee, has been set up by the Water Resourcess Board in conjunction with the Ministry of Housing and Local Government and the Trent River Authority. This committee is looking into the possible ways in which the present polluted waters of the Trent and some of its tributaries can be rehabilitated, and this project will evidently be helped along by the Water Pollution Laboratory, the latest annual report of which (HMSO, £1) says that about seven per cent of the laboratory's rescarch effort over the next three years will be devoted to a programme of research in connexion with the Trent and its pollution problems.

The Water Pollution Laboratory has other irons in the fire than river pollution. In 1967, coastal pollution was the largest single project in the laboratory's programme. This involved among other things the continuing development of methods of tracing the distribution of sewage from sewage outfalls in estuaries. Some of these techniques are being used to study the feasibility of disposing of London's sewage sludge through a pipeline terminating several miles offshore. This investigation is being carried out in collaboration with the Hydraulics Research Station and with a firm of consulting engineers on behalf of the Greater London Council. The cost of such a scheme would probably be about $£ 20$ million, but the present system by which sludge is dumped at a point about 70 miles from London Bridge in the Thames Estuary is becoming increasingly expensive.

\title{
Scientific Manpower in Britain and the USA; the McCurthy Study
}

ONE of the chief pieces of evidence commissioned by the Swann Committee, The Employment of Highly Specialized Graduates : a Comparative Study in the $U K$ and USA, by a young ICI economist, Mr M. C. McCarthy, was published on October 1 (HMSO, $4 s .6 d$.). The degree of specialization and the extent of the mismatch between the supply and demand for science based generalists in Britain, which Mr McCarthy has revealed, come as a rude surprise even after the Robbins report and the last few triennial surveys of engineers, technologists and scientists in Britain.

The difference between the education of the American generalist and the British specialist at undergraduate level is summarized simply in Tables 1 and 2, which speak for themselves. Between 65 and 75 per cent of

\begin{tabular}{|c|c|c|c|c|c|}
\hline \multirow[t]{2}{*}{ Table 1.} & \multicolumn{5}{|c|}{$\begin{array}{l}\text { Percentage of total programme devoted to } \\
\text { subjects other than major: }\end{array}$} \\
\hline & $\begin{array}{l}\text { Mathe- } \\
\text { matics }\end{array}$ & Science & $\begin{array}{l}\text { Humani- } \\
\text { ties, social } \\
e^{2} \text { science }\end{array}$ & $\begin{array}{l}\text { Elec- } \\
\text { tives }\end{array}$ & other \\
\hline \multicolumn{6}{|c|}{ matics Science science tives } \\
\hline $\begin{array}{l}\text { B.A. English } \\
\text { Natural science }\end{array}$ & $\begin{array}{l}2 \\
3-14\end{array}$ & $\begin{array}{l}7 \\
6-12\end{array}$ & $\begin{array}{l}31 \\
30-37\end{array}$ & $\begin{array}{l}29 \\
18-29\end{array}$ & $\begin{array}{l}4 \\
3\end{array}$ \\
\hline Social science & 2 & & $34-36$ & $28-29$ & $2-4$ \\
\hline B.S. Fngineering & $\begin{array}{c}12-14 \\
4-5\end{array}$ & $\begin{array}{l}13-28 \\
12-14\end{array}$ & $\begin{array}{l}36-19 \\
29-33\end{array}$ & $\begin{array}{c}3-8 \\
21-25\end{array}$ & $\begin{array}{l}3-7 \\
2-4\end{array}$ \\
\hline $\begin{array}{l}\text { Physical science at } \\
\text { mathematics }\end{array}$ & $11-15$ & $7-12$ & $32-33$ & $13-27$ & $3-4$ \\
\hline
\end{tabular}

